УДК 373:374 - 043.5:37.015.31:7 - 053.6

DOI: 10.37026/2520-6427-2021-105-1-23-27
Лариса СЕРИХ,

кандидат педагогічних наук, доцент,

дочент кафедри теоріі

і методики змісту освіти

К3 «Сумський обласний інститут

післядипломної педагогічної освіти»,

м. Суми, Україна

ORCID: 0000-0001-5290-8596

e-mail:Su181260slv@ukr.net

\title{
ДЕТЕРМІНАНТИ СПІЛЬНОЇ ДІЯЛЬНОСТІ ЗАКЛАДІВ ЗАГАЛЬНОЇ СЕРЕДНЬОЇ ТА ПОЗАШКІЛЬНОЇ ОСВІТИ В ЕСТЕТИЧНОМУ ВИХОВАННІ ПІДЛІТКІВ
}

\begin{abstract}
Анотація. У статті дотримуємося позииії, згідно з якою сучасна педагогічна теорія і практика не можуть вирішувати завдання взаємодї закладів загальної середньої та позашкільної освіти щодо естетичного виховання підлітків без урахування досягнень інших наук. Вважаємо, щзо визначення теоретико-методологічних засад, педагогічних умов взаємодії означених закладів $i$ сутнісних ознак естетичної вихованості підлітка можливе лише шляхом інтеграції філософських, соиіологічних, педагогічних та психологічних знань.

Розкрито детермінанти, завдяки яким сьогодні відбувається переосмислення системи освіти, відтворення та ретрансляиії знань, нової парадигми освіти й виховання. Якще сутність традиційної освіти полягає у відтворенні педагогічного досвіду згідно із заданим зразком, то інноваційна освіта забезпечує умови для випереджального зростання духовних потреб людини впродовж усього ї̈ життя.

Розглянуто розвиток індивідуальності особистості як вищу духовну цінність суспільства, головну продуктивну силу, в якій виявляється органічна єдність мети і засобу. Ціллю й сенсом життедіяльності людини є найважливіші иінності - життя, свобода, благополуччя, заради яких вона творить, бореться, мріє та вірить. Забезпечення реалізації циих иінностей є важливим завданням для України на шляху входження до світового
\end{abstract}

співтовариства. В означеному аспекті для всіх сфер соціального, культурного та політичного життя посилюється значення людиноцентризму як філософської рефлексї про людину.

До психолого-педагогічних детермінант взаємодії належать спільні дії, спрямовані на реалізацію поточних і перспективних завдань спільної діяльності із завершальним загальним результатом. За такої умови важливе суб' єктивне відображення результату індивідуальними й колективними суб' єктами взаємодіï.

Сьогодні загострюється потреба у розширенні діапазону можливостей та глибинної структуризаиії наукоємної складової потенціалу наиії. Важливо навчити індивіда співжситтю з іншими людьми й суспільними структурами, умінню регулювати різні психологічні, соцііальні, політичні, міжснаціональні конфлікти з дотриманням вимог культури плюралізму думок. Зважаючи на цее, у вихованні й соціалізації підлітків беруть участь сім'я, заклади освіти, дитячі угрупування, громадські організації тощзо. Найефективнішими у процесі виховання, на нашу думку, є взаємовідносини між закладами загальної середньої та позашкільної освіти.

Ключові слова: взаємодія, детермінанти взаємодї, заклади загальної середньої освіти, заклади позашкільної освіти, підлітки.

\section{Larisa SIERYKH,}

Ph.D. in Pedagogical Sciences,

Associate Professor,

Senior Lecturer at the Department

of Theory and Methods

of Educational Content Sumy

Regional Institute of Postgraduate Pedagogical

Education,

Sumy, Ukraine

ORCID: 0000-0001-5290-8596

e-mail:Su181260slv@ukr.net

\section{DETERMINANTS OF JOINT ACTIVITY OF GENERAL SECONDARY AND EXTRACURRICULAR EDUCATIONAL INSTITUTIONS IN AESTHETIC EDUCATION OF ADOLESCENTS}

Abstract. In the article we adhere to the position that
modern pedagogical theory and practice can not solve the problem of interaction of general secondary and extracurricular institutions in the aesthetic education of adolescents 
in accordance with today's requirements without taking into account the achievements of other sciences. We believe that the definition of theoretical and methodological principles, pedagogical conditions of interaction of general secondary and out-of-school education and essential features of aesthetic education of adolescents is possible only through the integration of philosophical, sociological, pedagogical and psychological knowledge.

The determinants are revealed, because today there is a rethinking of the education system of reproduction and retransmission of knowledge, a new paradigm of education and upbringing. If the essence of traditional education is to reproduce the pedagogical experience according to a given pattern, innovative education provides the conditions for the rapid growth of a person's spiritual needs throughout his life.

The development of the individuality of the individual is considered as the highest spiritual value of society, as the main productive force in which the organic unity of purpose and means is manifested. The purpose and meaning of human life are the most important values life, freedom, well-being, for which he creates, fights, dreams and believes. Ensuring the realization of these values is an important task for Ukraine on the path to joining the world community. In this aspect, for all spheres of social, cultural and political life, the importance of anthropocentrism as a philosophical reflection on man is growing.

The psychological and pedagogical determinants of interaction include joint actions aimed at the implementation of current and future tasks of joint activities with the final overall result. It is important that the subjective reflection of the result by individual and collective subjects of interaction.

Today, the need to expand the range of opportunities and deep structuring of the science-intensive component of the nation's potential is growing. It is important to teach an individual to coexist with other people and social structures. Be able to regulate various psychological, social, political, interethnic conflicts in compliance with the requirements of a culture of pluralism of opinion. Therefore, in the upbringing and socialization of adolescents involved: the family, educational institutions, children's groups and more. The most effective in education, in our opinion, are the relationships between institutions of general secondary and extracurricular education.

Key words: interaction, determinants of interaction, general secondary education institutions, out-of-school education institutions, teenagers.

Постановка проблеми. Важливі зміни в усіх сферах людської життєдіяльності, зокрема в культурному освоєнні людиною світу, значно вплинули на характер iii мислення, на якісні зміни у вирішенні проблем виховання та актуалізували необхідність його підвищення в закладах освіти. Зважаючи на це, зупинимося детальніше на висвітленні філософських, соціокультурних та психолого-педагогічних чинників, що детермінують становлення і розвиток особистості.

Аналіз наукових досліджень і публікацій. Глобальні інтеграційні процеси сучасного світу - це об'єктивна тенденція розвитку всіх сфер суспільного життя. Означена наукова думка аналізується у працях В. Андрущенка, О. Биковської, Ф. Ващука, С. Гончаренка, В. Кременя, О. Левченко, С. Ніколаєнка, В. Слободчикова, С. Ісаєва, Ю. Тихонравова, В. Химинець та інших науковців. Глобальні процеси «охопили суспільне виробництво, культуру, духовне життя, освітню та наукову сферу, ставши визначальними факторами формування способу та якості життя всього світу та окремих державно-організованих суспільств» (Ващук, 2011, с. 6).

Мета статті - дослідити філософські, соціокультурні та психолого-педагогічні детермінанти взаємодії закладів загальної середньої та позашкільної освіти.

Виклад основного матеріалу дослідження. Освіта, перетворившись на продуктивну силу, стала предметом пріоритетної уваги національної та міжнародної політики. У зв'язку з цим окреслюються нові тенденції якості освіти - упровадження інноваційних технологій, які за останнє десятиліття якісно розвинулись у форматі геометричної прогресії. «Той, хто володіє інформацією, володіє всім світом»-цей вислів уже не $\epsilon$ основовизначальним у розумінні успішної стратегії розвитку. Той, хто продукує знання (інформацію, технології), здатен впливати на хід будь-якого процесу. В означеному контексті відбувається гуманітаризація наукових знань, що забезпечує розвиток особистості в контексті загальної культури, гуманізація стосунків, що передбачає визнання прав особистості на унікальність, внутрішню свободу та активність, здатність кожної людини до розвитку і самореалізації своїх сутнісних сил, здібностей і талантів.

У світлі нової освітньої парадигми людина, яка навчається, розглядається як складна відкрита система. У зв'язку з цим освітня діяльність має грунтуватися на основних положеннях і принципах синергетики як важливої складової сучасної філософії освіти, а формування особистості здійснюватися в результаті цілеспрямованого виховання. Визначальну роль за цієї умови відіграє систематична діяльність як закладів загальної середньої освіти (далі - 33СO), так і закладів позашкільної освіти (далі - ЗПО), оскільки у цих закладах формуються всі базові ціннісні орієнтації та мотивація соціальної поведінки, засвоюються основні соціальні норми та відносини.

Отже, глобалізацію, інформатизацію та гуманізацію суспільних відносин, які зумовили посилення ролі людини у всіх сферах життєдіяльності, визначаємо соиіокультурними детермінантами взаємодії З3СО та ЗПО в естетичному вихованні підлітків як на суспільному, так і на особистісному рівнях.

На відміну від філософії минулого на сучасному етапі запропоновано «нову філософію освіти, яка узагальнює різні, найбільш прогресивні ідеї: філософію всеєдності, глобальної освіти, філософію серця, життєтворчості, діалогу культур, ідеї синергетики та інші. Сучасна філософія освіти пропонує замість діалектико-матеріалістичної методології використовувати синергетичний, структурно-функиіональний, логіко-когнітивний, неопозитивістський, феноменологічний, антропологічний, теологічний, аксіологічний та інші принципи і підходи» (Скубашевська, 2010, с. 11). 3 огляду на це освіта й виховання повинні формувати людину, органічно адаптовану до життя в світі 3 різноманіттям зв'язків - від контактів із найближчим оточенням до глобальних комунікацій.

Найбільш повно, на нашу думку, означена ідея концептуалізована у наукових доробках академіка В. Кременя (2011), який наголошує, що «людиноцентризм - це нова якість філософського розуміння людини, котра переважає як масштаби ренесансного 
антропоцентризму і гуманізму, так і філософської антропології, оскільки виходить за їх межі». Зауважимо, що саме філософія людиноиентризму найбільш дотична до проблем сучасного буття, з якого продукується свідомість, духовність, ідентичність, ијннісна основа "Я-кониепиї» особистості.

Проаналізувавши філософські детермінанти взаємодії ЗЗСО та ЗПО, визначаємо сутність педагогічної взаємодії, зміст та смисл якої розкриваються як на рівні окремих контактів, так і в контексті спільної діяльності. Розкриття педагогічної взаємодії як дефініції вимагає психолого-педагогічного аналізу поняття «взаємодія» і дозволяє окреслити його психолого-педагогічні детермінанти. Поняття «взаємодія» складається 3 двох коренів - «взаємо» та «дія» і означає «взаємний», «обопільний, який стосується обох сторін» (Ожегов, 1991). У взаємодії передбачається участь різних суб'єктів, проте їх може бути не лише два (як на це вказує визначення «обопільний»). Серед структур взаємодії слушною є модель діадичної взаємодії, котру обгрунтували американські психологи Д. Тібо та М. Келлі (1998). Сутність моделі зводиться до таких положень: будь-які міжособистісні взаємини є взаємодією, реальним обміном поведінковими реакціями в межах певної ситуації тощо; важливим психолого-педагогічним чинником спільної діяльності є спільна мотивація; умовою виконання спільної діяльності є процеси розподілу, об'єднання, погодження, управління індивідуальними цілями, мотивами, діями й результатами (Сутність взаємодії: вебсайт, 2013, с. 2). Усе це в межах нашого дослідження дозволяє організовувати, планувати, здійснювати освітньо-виховну взаємодію ЗЗСО та ЗПО відповідно до визначеної мети і цілей естетичного виховання підлітків.

Спілкуючись, «обмінюючись інформацією, людина формує норми й форми спільних дій, організовує й координує їх, завдяки чому уникає розриву між комунікацією та взаємодією. За цих умов структуру взаємодії 3ЗСО та ЗПО визнаємо як систематичні, регулярні дії суб'єктів, спрямованих один на одного, мета яких - викликати відповідну реакцію, котра зумовлюватиме нову реакцію того, хто здійснює вплив. Розглядаючи типологію партнерства, С. Жданенко (2002, с. 85) характеризує взаємодію «з точки зору свідомого регулювання взаємин між суб'єктами як механізм забезпечення соціальної злагоди та визначає такі ії процедурні елементи, як-от: діалог, компроміс, консенсус, розподіл видів діяльності, кооперація». У цьому контексті діалог, що здійснюється у формі дискусій, медіації, фасилітації, конференцій, круглих столів, обговорення актуальних проблем у пресі, на телебаченні і за допомогою мережі Інтернет, виконує функцію забезпечення взаєморозуміння представників різних соціальних груп, державних установ та iн. Стає очевидним, що партнерство передбачає не лише досягнення домовленостей між суб'єктами, а й спільні зусилля, що здійснюються шляхом розподілу видів діяльності й кооперації та які спрямовані на досягнення загальних і індивідуальних цілей партнерської взаємодії. Таким чином, ми запроваджуємо міжсуб'єктну взаємодію З3СО та ЗПО, що спрямована на досягнення загальних та індивідуальних цілей естетичного виховання підлітків.

Проблема «педагогічної взаємодії» в освітньому процесі досліджувалася науковцями в різних аспектах, зокрема: взаємодія викладача й студента та характер дидактичної емоційної В3 під час організації самостійної роботи; «педагогічна взаємодія» й «педагогічне спілкування» як взаємодія вчителя й учня; «виховна взаємодія», спрямована на формування особистості учня; «емоційна взаємодія» як компонент педагогічної системи; «дидактична взаємодія» педагога й учня як фактор оптимізації процесу навчання; посилення інтелектуального та емоційного взаємозв'язку у процесі навчання й виховання; взаємодія $33 \mathrm{CO} з$ іншими інституціями (сім'єю, творчими, спортивними об'єднаннями, музеями та ін.). Так, до психолого-педагогічних детермінант належить художньо-естетичне спілкування, умовою якого, на думку В. Орлова, є діалог між трьома суб'єктами: викладачем, студентом, твором мистецтва. Це діалог студента, викладача й автора художнього твору. Особливістю такого спілкування є виконання специфічної вимоги до уроку мистецтва, умова говорити зі студентами мовою мистецтва (Орлов, 2003). Взаємодія З3СО та ЗПО спрямована не тільки на діалог із мистецтвом у тріаді «керівник гуртка - вихованець - твір мистецтва», але й дозволяє освоїти підліткам весь комплекс методів і механізмів творчої естетичної діяльності.

Характеризуючи педагогічну взаємодію у структурі спільної діяльності, К. Приходченко (2007) виокремлює предметно спрямовані (цільові) взаємодії, що змінюють структури індивідуальної діяльності ії учасників, підкоряючи їх загальним цілям і завданням. Тобто взаємодія перетворює, перебудовує виконувану діяльність з індивідуальної у спільну, спрямовуючи таким чином виховний потенціал на підлітків. Дослідницею О. Саркісовою (2013) встановлено, що в педагогічному аспекті взаємодія розглядається як «неодмінна складова навчання спільної діяльності; у соціологічному - розкривається в контексті їі значущості для певної соиіальної спільноти, групи; у психологічному - характеризується як система взаємообумовлених дій між окремими особами та групами, процесуальна сторона діяльності». Взаємодія впливає як на педагогів 3ЗСО та ЗПО, так і на підлітків у міру їх власної особистісної активності. Взаємодія у колективній діяльності виявляється у формі ії організації, тобто спільних дій, спрямованих на загальний предмет праці. Саме спільні дії сприяють використанню основних структурних складових діяльності (цілей, мотивів тощо) (Нечволод, 2008).

Наведені твердження характеризують «взаємодію» як процес, що складається з фізичного (спільне переміщення в просторі, спільні дії) й духовного контактів. Йдеться про те, що в організації колективної діяльності наявні такі основні аспекти, які характеризують взаємодію як процес: індивіди, які діють, спільні дії, інформаційні зв'язки, взаємовплив, взаємостосунки, взаєморозуміння.

До соціокультурних детермінантів взаємодії належить також залучення учасників освітнього процесу до соціальної взаємодії, що реалізується в обміні діяльністю, інформацією, досвідом, здібностями, уміннями тощо, об'єктивною основою якої є спільність чи розбіжність інтересів, близьких чи віддалених цілей тощо. Для цієї взаємодії використовується термін «інтеракція» - динамічна взаємодія і співвідношення між двома чи більше перемінними, згідно з якими величина однієї перемінної впливає на величину інших змінних. 
Дослідники К. Десятник, Л. Зінченко, О. Кіян, О. Ковальчук розглядають психолого-педагогічні детермінанти взаємодії (сім’ї і школи, сім’і, школи і громадськості, батьківсько-вчительську взаємодію). Так, О. Кіян $(2011$, с. 8). визначає взаємодію як «процес спільної діяльності, спрямований на реалізацію активності одного суб'єкта щодо об'єкта або щодо іншого суб'єкта (у спілкуванні)». При цьому провідним, об'єднуючим органом є ЗПО, оскільки ефективність естетичного виховання підлітків значною мірою залежить від уміння педагогів працювати з підлітками, спрямовувати спільну діяльність з учнями 33СО в естетичному вихованні, яке інтегрувало б вимоги ЗЗСО та ЗПО, гармонізувало їх взаємини щодо естетичного розвитку підлітків. Л. Зінченко (2013), аналізуючи дослідження психологів, доводить, що взаємодія має «інтерсуб'єктний характер, ознаками якої $€$ : предметність; ситуативність або регламентованість певними обставинами; рефлективність - можливість для взаємодії бути впливом як суб'єктивних намірів, так і наслідком спільної участі в колективній діяльності; експлікованість - можливість спостереження, реєстрації конкретних дій індивідів, суб'єктів взаємодії», що дозволяє розглядати взаємодію З3СО та ЗПО в естетичному вихованні підлітків як інтегрувальний чинник, за допомогою якого відбувається поєднання частин у певний тип цілісності - структуру (систему) взаємодії 3ЗСО та ЗПО в естетичному вихованні підлітків. Взаємодію як «процес взаємовпливу суб'єктів один на одного в системі спільної особистісно зорієнтованої діяльності освітнього закладу» розглядає О. Ковальчук (2013). На його думку, це дозволяє формувати в підлітків естетичні цінності та якості, мотивувати їх до будь-якої діяльності, зокрема творчої, естетичної, здійснювати конструктивний діалог, що призводить до якісних змін суб'єктів і об'єктів взаємодії З3СО та ЗПО.

У контексті педагогічної взаємодії особливо важливим $\epsilon$ те, що естетична діяльність у педагогічному процесі відображає життя підлітків, формує критерії оцінки явищ дійсності, характерів та вчинків. На організацію та виявлення педагогічних умов емоційної взаємодії спрямований науковий пошук I. Гапійчук. Позитивна взаємодія, на її думку, визначає емоиійний потенціал суб'єктів процесу навчання, дозволяє акумулювати пізнавальну активність, суттєво підвищувати рівень мотивації та ефективність процесу навчання у цілому (Гапійчук, 2003). За допомогою емоцій людина може впливати на партнера взаємодії, змінюючи його реакцію на предмет обговорення.

Пошук нових можливостей взаємодії $33 \mathrm{CO}$ та ЗПО в естетичному вихованні підлітків націлив на розуміння того, що ЗПО має стати додатковим, допоміжним, добровільним місцем відвідування підлітків із максимальним урахуванням їхніх найрізноманітніших художньо-естетичних інтересів, а педагог - організатором і посередником естетичного виховання.

Висновки та перспективи подальших досліджень. Розглянувши філософські, соціокультурні та психолого-педагогічні детермінанти взаємодії З3СО та ЗПО, у взаємодії передбачається залучення до освітнього процесу таких суб'єктів навчання: учнів, вихованців, учителів, керівників гуртків, психологів, заступників директорів з виховної роботи, батьків, педагогів-орга- нізаторів та ін. 3'ясовано, що провідним, об'єднуючим органом у процесі взаємодії ЗЗСО та ЗПО є заклад позашкільної освіти, оскільки ефективність естетичного виховання підлітків значною мірою залежить від переконувального діалогу вихователів і вихованців на засадах партнерства, справедливості, взаємоповаги, вміння педагогів спрямовувати спільну діяльність на створення естетико-виховного середовища, яке інтегрувало б $33 \mathrm{CO}$ та ЗПО, гармонізувало їх взаємини в естетичному розвитку особистості підлітка, спрямовувало його прагнення практично реалізувати бажану цінність.

\section{СПИСОК ВИКОРИСТАНОЇ ЛІТЕРАТУРИ}

Інтеграція в європейський освітній простір: здобутки, проблеми, перспективи: монографія (2011) / за заг. ред. Ф. Г. Ващука. Ужгород: ЗакДУ.

Скубашевська, О. С. (2010). Філософія інноваційного розвитку освіти в умовах становлення інформаційного суспільства в Україні: автореф. дис. ... д-ра філос. наук: 09.00.10 «Філософія освіти». Київ: НПУ ім. М. Драгоманова.

Кремень, В. Г. (2011). Філософія людиноцентризму в освітньому просторі. 2-е вид. Київ: Т-во «Знання України».

Ожегов, С. И. (1991). Словарь русского языка. Москва: Русский язык. York.

Kelly, M. (1998). Encyclopedia of aesthetics. New

Сутність взаємодії: вебсайт. URL: http://www. novapedahohika.com/noloms (дата звернення: 10.01.2021).

Жданенко, С. Б. (2002). Партнерство як соціальний інститут. Наукові записки Харківського військового університету. Харків: ХВУ. ХV. С. 85-89.

Орлов, В. Ф. (2003). Професійне становлення вчителів мистецьких дисциплін: монографія / за заг. ред. I. А. Зязюна. Київ: Наукова думка.

Приходченко, К. І. (2007). Формування творчого освітньо-виховного середовища в загальноосвітніх закладах гуманітарного спрямування: навчальний посібник. Донецьк: ДНТУ.

Саркісова, О. Ю. (2013). Групова взаємодія як умова ефективної професійної підготовки майбутніх викладачів економіки: автореф. дис. ... канд. пед. наук: 13.00.04. Київ: Нац. авіаційний ун-т.

Нечволод, Л. І. (2008). Сучасний словник іншомовних слів. Харків: ТОРСІНГ ПЛЮС.

Кіян, О. І. (2011). Батьківсько-вчительська взаємодія як чинник морально-духовного виховання молодших підлітків: автореф. дис. ... канд. пед. наук: 13.00.07 «Теорія та методика виховання». Київ: Ін-т проблем виховання.

Зінченко, Л. В. (2013). Взаємодія сім’ї, школи та громадськості у вітчизняній педагогічній теорії і практиці (1946-1991 рр.): автореф. дис. ... канд. пед. наук: 13.00.01 «Загальна педагогіка та історія педагогіки». Ялта.

Ковальчук, О. В. (2013). Взаємодія сім’ї і школи у формуванні гуманістичних цінностей дітей молодшого шкільного віку : автореф. дис. ... канд. пед. наук: 13.00.07 «Теорія та методика виховання». Київ.

Гапійчук, I. М. (2003.) Педагогічні умови емоційної взаємодії «викладач-студент» у процесі навчання у класичному університеті: дис. ... канд. пед. наук. URL: https://www.google.com.uabiblioteka.cdu.edu.ua/ cgibin (дата звернення: 12.01.2021). 


\section{REFERENCES}

Intehratsiia $\mathrm{v}$ yevropeiskyi osvitnii prostir: zdobutky, problemy, perspektyvy: monohrafiia [Integration into the European educational space: achievements, problems, prospects: monograph]. (2011) / Uzhhorod: ZakDU. [in Ukrainian].

Skubashevska, O. S. (2010). Filosofiia innovatsiinoho rozvytku osvity v umovakh stanovlennia informatsiinoho suspilstva v Ukraini [Philosophy of innovative development of education in the conditions of formation of information society in Ukraine]: avtoref. dys. ... d-ra filos. nauk: 09.00.10 «Filosofiia osvity». Kyiv: NPU im. M. Drahomanova. [in Ukrainian].

Kremen, V. H. (2011). Filosofiia liudynotsentryzmu v osvitnomu prostori [Philosophy of anthropocentrism in the educational space]. 2-e vyd. Kyiv: T-vo «Znannia Ukrainy». [in Ukrainian].

Ozhehov, S. Y. (1991). Slovar russkoho yazыka [Dictionary of the Russian language]. Moskva: Russkyi yazыk. [in Russia].

Kelly, M. (1998). Encyclopedia of aesthetics. New York. [in Ukrainian].

Sutnist vzaiemodii [The essence of interaction]: vebsait. URL: http://www.novapedahohika.com/noloms (data zvernennia: 10.01.2021). [in Ukrainian].

Zhdanenko, S. B. (2002). Partnerstvo yak sotsialnyi instytut [Partnership as a social institution]. Naukovi zapysky Kharkivskoho viiskovoho universytetu. Kharkiv: KhVU. KhV. S. 85-89. [in Ukrainian].

Orlov, V. F. (2003). Profesiine stanovlennia vchyteliv mystetskykh dystsyplin [Professional development of teachers of art disciplines]: monohrafiia / za zah. red. I. A. Ziaziuna. Kyiv: Naukova dumka. [in Ukrainian].

Prykhodchenko, K. I. (2007). Formuvannia tvorchoho osvitno-vykhovnoho seredovyshcha $\mathrm{v}$ zahalnoosvitnikh zakladakh humanitarnoho spriamuvannia [Formation of a creative educational environment in general educational institutions of humanitarian direction]: navchalnyi posibnyk. Donetsk: DNTU. [in Ukrainian].
Sarkisova, O. Yu. (2013). Hrupova vzaiemodiia yak umova efektyvnoi profesiinoi pidhotovky maibutnikh vykladachiv ekonomiky [Group interaction as a condition for effective professional training of future teachers of economics]: avtoref. dys. ... kand. ped. nauk: 13.00.04. Kyiv: Nats. aviatsiinyi un-t. [in Ukrainian].

Nechvolod, L. I. (2008). Suchasnyi slovnyk inshomovnykh sliv [Modern dictionary of foreign words]. Kharkiv: TORSINH PLIuS. [in Ukrainian].

Kiian, O. I. (2011). Batkivsko-vchytelska vzaiemodiia yak chynnyk moralno-dukhovnoho vykhovannia molodshykh pidlitkiv [Parent-teacher interaction as a factor in the moral and spiritual upbringing of young adolescents]: avtoref. dys. ... kand. ped. nauk: 13.00.07 «Teoriia ta metodyka vykhovannia». Kyiv: In-t problem vykhovannia. [in Ukrainian].

Zinchenko, L. V. (2013). Vzaiemodiia simi, shkoly ta hromadskosti u vitchyznianii pedahohichnii teorii i praktytsi (1946-1991 rr.) [Interaction of family, school and community in domestic pedagogical theory and practice (1946-1991)]: avtoref. dys. ... kand. ped. nauk: 13.00.01 «Zahalna pedahohika ta istoriia pedahohiky». Yalta. [in Ukrainian].

Kovalchuk, O. V. (2013). Vzaiemodiia simi i shkoly u formuvanni humanistychnykh tsinnostei ditei molodshoho shkilnoho viku [Interaction of family and school in the formation of humanistic values of children of primary school age]: avtoref. dys. ... kand. ped. nauk: 13.00.07 «Teoriia ta metodyka vykhovannia». Kyiv. [in Ukrainian].

Hapiichuk, I. M. (2003.) Pedahohichni umovy emotsiinoi vzaiemodii «vykladach-student» u protsesi navchannia u klasychnomu universyteti [Pedagogical conditions of emotional interaction «teacher-student» in the process of studying at a classical university]: dys. ... kand. ped. nauk. URL: https://www.google.com.uabiblioteka.cdu. edu.ua/cgibin (data zvernennia: 12.01.2021). [in Ukrainian].

Дата надходження до редакиії 25.01. 2021 р. 